University of Nebraska - Lincoln

DigitalCommons@University of Nebraska - Lincoln

Faculty Publications: Department of Entomology

2018

Description of a New Species of Stenocrates Burmeister (Coleoptera: Scarabaeidae: Dynastinae: Cyclocephalini) from Peru

Brett C. Ratcliffe

University of Nebraska-Lincoln, bratcliffe1@unl.edu

Luis Figueroa

Museo de Historia Natural de UNMSM - Lima, luis_thecell@hotmail.com

Follow this and additional works at: https://digitalcommons.unl.edu/entomologyfacpub

Part of the Entomology Commons

Ratcliffe, Brett C. and Figueroa, Luis, "Description of a New Species of Stenocrates Burmeister (Coleoptera: Scarabaeidae: Dynastinae: Cyclocephalini) from Peru" (2018). Faculty Publications: Department of Entomology. 751.

https://digitalcommons.unl.edu/entomologyfacpub/751

This Article is brought to you for free and open access by the Entomology, Department of at DigitalCommons@University of Nebraska - Lincoln. It has been accepted for inclusion in Faculty Publications: Department of Entomology by an authorized administrator of DigitalCommons@University of Nebraska - Lincoln. 


\title{
Description of a New Species of Stenocrates Burmeister (Coleoptera: Scarabaeidae: Dynastinae: Cyclocephalini) from Peru
}

\author{
Brett C. Ratcliffe \\ Systematics Research Collections \\ W436 Nebraska Hall, University of Nebraska \\ Lincoln, NE 68588-0514, USA \\ bratcliffe1@unl.edu \\ AND \\ LUIS FigueroA \\ Departamento de Entomología \\ Museo de Historia Natural de la Universidad Nacional Mayor de San Marcos \\ Apartado Postal 14-0434, Lima, PERU \\ luis_thecell@hotmail.com
}

\begin{abstract}
A new species of Stenocrates Burmeister, 1847 (Coleoptera: Scarabaeidae: Dynastinae: Cyclocephalini) from Peru is described: Stenocrates lissothorax Ratcliffe and Figueroa. A description, diagnosis, distribution, and illustrations of the new species are provided. This represents the $52^{\text {nd }}$ species in the genus, and the $15^{\text {th }}$ species known from Peru.
\end{abstract}

Key Words: taxonomy, scarab beetles, Neotropics, evergreen montane forest

DOI.org/10.1649/0010-065X-72.4.797

Zoobank.org/urn:lsid:zoobank.org:pub:8B7A536A-ED20-45BB-901A-0753F719B12C

The genus Stenocrates Burmeister, 1847 now has 52 species, including the new species described herein. This new species is the $15^{\text {th }}$ known from Peru (Ratcliffe et al. 2015 and subsequent personal observations). Stenocrates species are widely distributed from Mexico to Argentina, with most occurring in South America, and one species is known from the West Indies. Most species are externally similar and difficult to nearly impossible to distinguish from one another based upon only external characteristics, and so great reliance is made on the form of the male parameres for identification. Most females not associated with males cannot usually be identified with reliability, even by being taken in the same collecting event since some species are sympatric with one another. This is one of the most difficult genera of Dynastinae in the Americas to identify because of the external similarity of the species. Because of the high number of cryptic species in Stenocrates, new species continue to be discovered and described.

Unlike most other species in the tribe Cyclocephalini, the males of Stenocrates species do not have enlarged protarsal claws. Species in the genus are characterized by a relatively short, subtrapezoidal clypeus that has its apex truncate to slightly emarginate; a distinct frontoclypeal suture; three pairs of punctate striae on the elytra; and the meso- and metafemora strongly flattened. The antenna has ten antennomeres and a small club. The immature stages remain unknown for all Stenocrates species. Life history information is also lacking. The adults are attracted to lights.

Endrödi $(1966,1985)$ provided the last synopsis of the genus (26 species), but 26 new species have been described since that time, including the new one described herein. These remain unincorporated in any key (a difficult task when emphasis must be placed on the parameres), and so a new key to species is needed. The most recent comprehensive checklist is by Ratcliffe (2015).

\section{Material and Methods}

The species description below is based on specimens originally deposited in the collections of the Snow Entomology Museum at the University of Kansas. Characters used in the description are the length from the front of the head to the apex of the pygidium; width across the humeri; interocular width (number of transverse eye diameters across the frons between the eyes); form and sculpturing of the head, pronotum, elytra, and pygidium; form of the protibia, prosternal process, and parameres. Punctures are considered simple unless otherwise noted. Minute punctures are generally not seen with $12.5 \mathrm{X}$ magnification but are easily seen with $50 \mathrm{X}$ magnification. Small punctures are easily seen with 

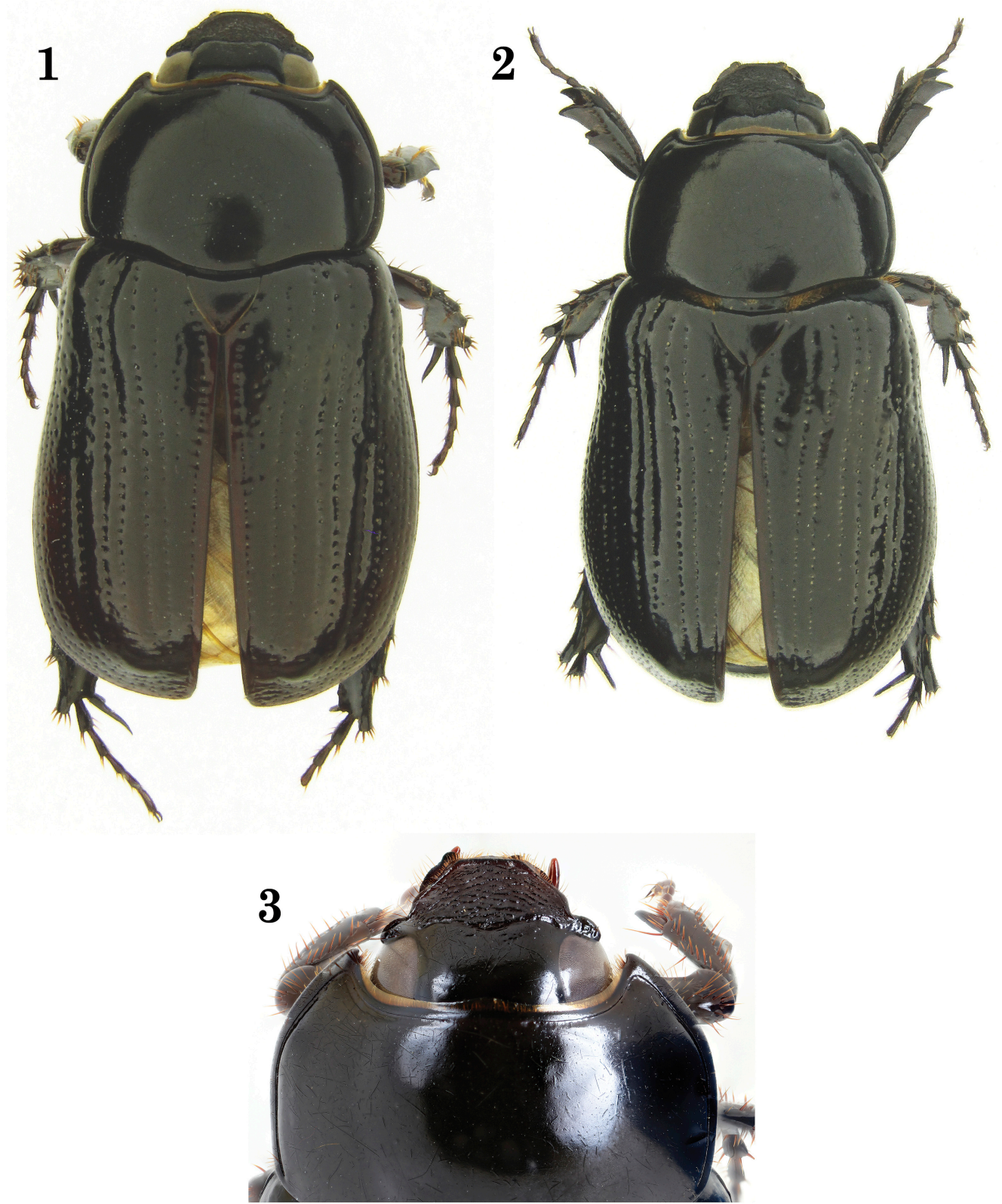

Figs. 1-3. Stenocrates lissothorax. 1) Male holotype; 2) Female allotype; 3) Female paratype, head and pronotum.

12.5X magnification and can be seen with the naked eye. Large punctures are easily seen without the aid of instruments. Sparse punctures are characterized by numerous puncture diameters between them. Punctures moderate in density have 3-5 puncture diameters between them. Dense punctures have only 1-2 puncture diameters between them or less. Label data is quoted verbatim.
A single slash (/) indicates a break between lines on the same label, and a double slash (//) indicates a different label.

We use the phylogenetic species concept as outlined by Wheeler and Platnick (2000). This concept defines species as the smallest aggregation of (sexual) populations diagnosable by a unique combination of character states. 


\section{Stenocrates lissothorax Ratcliffe and Figueroa, new species \\ (Figs. 1-4, 6-7) \\ Zoobank.org/urn:lsid:zoobank.org:act: 11DE5A8B-8DCC-4D40-B73B-1798A6AF2FF8}

Type Material. Holotype labeled "PERU: Amazonas: Bongara, / Corosha, Beirut, Rocota trail, / S05 49'4.4" W7749'19.1", 2004m / 19.XI.2016. leg. M. Alvarado, L. / Breitkreuz, J. Thomas, light trap, / PERU1ABT16010 // bar code SEMC1549291 / KUNHM-ENT" and with our red holotype label. Allotype with same data and "bar code SEMC1549264 / KUNHM-ENT" and with our red allotype label. Two male and three female paratypes with same data and bar codes of "SEMC1549265 / KUNHM-ENT", "SEMC1549266 / KUNHM-ENT", "SEMC1549268 / KUNHM-ENT", "SEMC1549279 / KUNHM-ENT", "SEMC1549267 / KUNHM-ENT" and our yellow paratype labels. Holotype and allotype deposited at the Museo de Historia Natural de la Universidad Nacional Mayor de San Marcos, Lima, Peru; three paratypes (one male, two females) deposited at the Snow Entomology Museum, University of Kansas, Lawrence, KS, USA, and two paratypes (one male, one female) in the B. C. Ratcliffe collection (Lincoln, NE, USA.

Description. Holotype. Male (Fig. 1). Length $17.2 \mathrm{~mm}$; width across humeri $7.8 \mathrm{~mm}$. Color black. Head: Frons smooth, shiny, with small, indistinct, roughened field of shallow punctures at center apex. Frontoclypeal suture distinctly impressed, arcuate, lacking carinulate ridge in front of suture. Clypeus coarsely, completely, transversely rugose; apex subtruncate (feebly convex) (as in Fig. 3). Interocular width equals 2.5 transverse eye diameters.
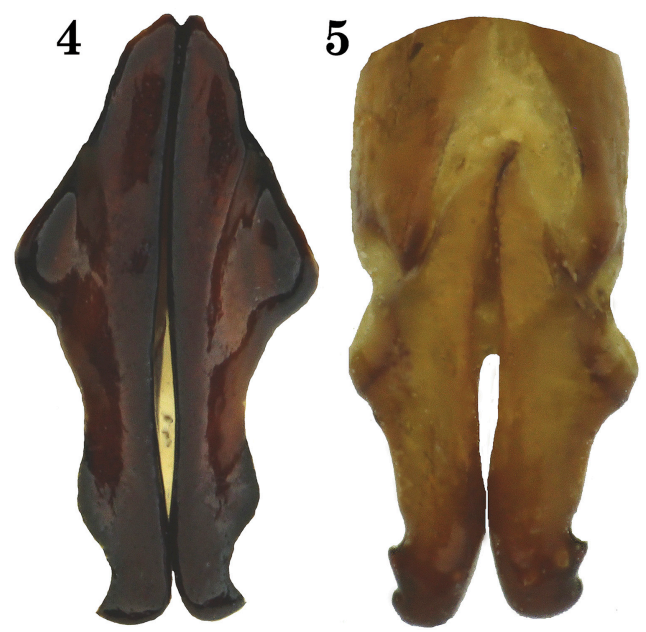

Figs. 4-5. Stenocrates species, parameres. 4) $S$. lissothorax; 5) S. holomelanus.

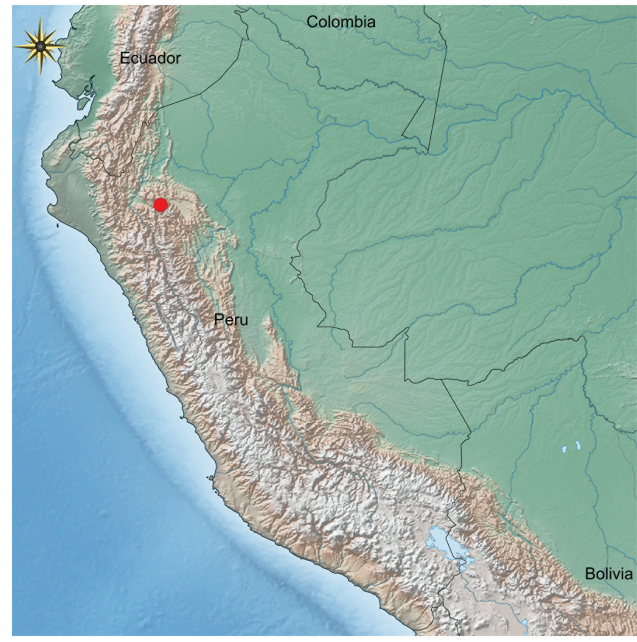

Fig. 6. Stenocrates lissothorax distribution map.

Antenna with 10 antennomeres, club subequal in length to antennomeres 2-7. Pronotum: Surface shiny, completely smooth, with indistinct, sparse micropunctures (as in Fig. 3). Lateral margins with thick marginal bead, base lacking marginal bead.

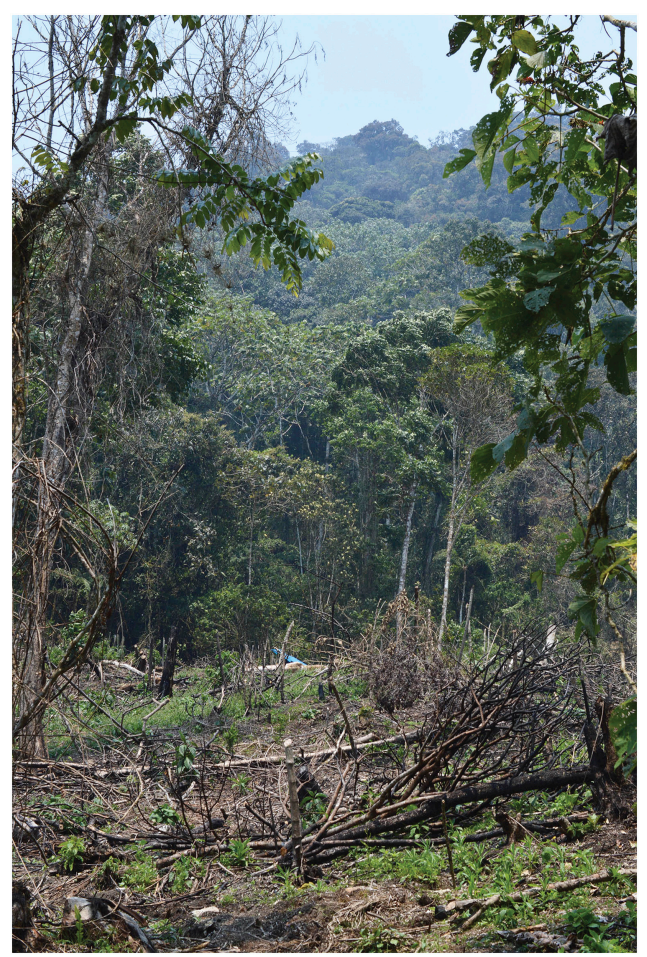

Fig. 7. Stenocrates lissothorax type locality near Beirut municipality, Amazonas, Peru. Photograph by Laura Breitkreuz (University of Kansas). 
Elytra: Surface shiny, with punctate sutural stria and 2 pairs of distinct discal striae and 1 pair of striae behind humerus; each stria comprised of large, deep, closely adjacent punctures. First broad interval with single, irregular row of similar punctures, second broad interval lacking punctures. Pygidium: Surface shiny, completely and moderately densely punctate, punctures less dense on apical third; punctures moderately large, glabrous. In lateral view, surface weakly convex. Legs: Protibia tridentate, basal tooth slightly removed from other teeth. Metatarsus shorter than metatibia. Venter: Prosternal process long, thick; in lateral view, columnar, flared posteriorly at base, apex narrowly rounded into 2 small prominences, each prominence with several long setae; in ventral view, apex a subtriangular cone. Parameres: Form widest just above middle, lateral margins flared above apices, apices stout and curving away from one another (Fig. 4).

Allotype. Female (Fig. 2). Length $19.6 \mathrm{~mm}$; width across humeri $9.5 \mathrm{~mm}$. The allotype does not differ significantly from the holotype.

Variation. Males (two paratypes): Length 17.0$17.7 \mathrm{~mm}$; width across humeri $8.0-8.2 \mathrm{~mm}$. The male paratypes do not differ significantly from the holotype. Females (three paratypes): Length 18.3$20.0 \mathrm{~mm}$; width across humeri $8.4-9.3 \mathrm{~mm}$. The female paratypes do not differ significantly from the allotype.

Etymology. The epithet is derived from the Greek lissos meaning smooth or polished and the Greek thorax referring to a breastplate. The specific epithet is used as a noun in apposition and means "the smooth thorax" in reference to the completely smooth pronotum of this species.

Distribution. Stenocrates lissothorax is known only from Amazonian Peru (Fig. 6).

Locality Records. PERU (7). Amazonas Region (7): Bongara Province, Corosha District, Beirut Municipality, Rocota trail.

Temporal Distribution. November (7).

Diagnosis. The form of the parameres is essential for distinguishing species of Stenocrates because their external body morphology is, with few exceptions, so similar. The parameres of $S$. lissothorax are unique but vaguely resemble those of Stenocrates holomelanus (Germar, 1824) (compare Figs. 4 and 5). However, S. holomelanus is small $(12-15 \mathrm{~mm})$, whereas $S$. lissothorax is larger $(17-20 \mathrm{~mm})$. In addition, the surface of the pronotum is entirely smooth in $S$. lissothorax (hence its specific epithet) but variably punctate in all other species of Stenocrates known from Peru.

Natural History. The specimens were taken at lights at 2,000 $\mathrm{m}$ in an area of evergreen montane forests (Fig. 7). As with virtually all species of Stenocrates, nothing is known of the life history of S. lissothorax.
Remarks. Stenocrates species recorded from Peru are Stenocrates bicarinatus Robinson, 1948; Stenocrates carbo Prell, 1937; Stenocrates celatus Prell, 1937; Stenocrates clipeatus Endrödi 1966; Stenocrates cognatus Endrödi, 1966; Stenocrates cultor Burmeister, 1847; Stenocrates haackae Ratcliffe, 1977; S. holomelanus; S. lissothorax; Stenocrates mimeomus Ratcliffe, 2015; Stenocrates minutus Endrödi, 1966; Stenocrates nasutus Dechambre, 1979; Stenocrates omissus Endrödi, 1966; Stenocrates popei Endrödi, 1971; and Stenocrates serendipitus Ratcliffe, 2015.

\section{Acknowledgments}

We thank Jennifer Thomas and Zack Falin (Snow Entomology Museum, University of Kansas, Lawrence, KS, USA) for making specimens available for study and for permission to distribute paratypes to other collections. Laura Breitkreuz (Department of Ecology and Evolutionary Biology, University of Kansas, Lawrence, KS, USA) generously shared the habitat photograph. Angie Fox (Scientific Illustrator, University of Nebraska State Museum, Lincoln, NE, USA) provided the line drawings of the parameres. The research permit (365-2016-SERFOR/ DGGSPFFS) for this project was issued by the Peruvian Ministry of the Environment.

\section{References Cited}

Endrödi, S. 1966. Monographie der Dynastinae (Coleoptera, Lamellicornia). I. Teil. Entomologische Abhandlungen 33: 1-460.

Endrödi, S. 1985. The Dynastinae of the World. Dr. W. Junk Publisher, Dordrecht, The Netherlands.

Ratcliffe, B. C. 2015. A revised catalog of the species of Stenocrates Burmeister (Coleoptera: Scarabaeidae: Dynastinae: Cyclocephalini), with descriptions of three new species from Peru and Brazil and Stenocrates inpai Ratcliffe, 1978 placed in junior synonymy with Stenocrates popei Endrödi, 1971. The Coleopterists Bulletin 69: 773-779.

Ratcliffe, B. C., M. L. Jameson, L. Figueroa, R. D. Cave, M. L. Gimmel, M. J. Paulsen, E. B. Cano, C. Beza-Beza, L. Jimenez-Ferbans, and $P$. Reyes-Castillo. 2015. Beetles (Coleoptera) of Peru. A survey of the families. Scarabaeoidea. Journal of the Kansas Entomological Society 88: 186-207.

Wheeler, Q. D., and N. I. Platnick. 2000. The phylogenetic species concept (sensu Wheeler and Platnick) [pp. 55-69]. In: Species Concepts and Phylogenetic Theory. A Debate (Q. D. Wheeler and R. Meier, editors). Columbia University Press, New York, NY.

(Received 19 March 2018; accepted 9 August 2018. Publication date 28 December 2018.) 